\title{
Cytogenetic analysis in different populations of Rhodnius prolixus and $R$. nasutus from different countries of South America
}

\author{
A. Ravazi ${ }^{a}$, K. C. C. Alevi ${ }^{*}$, J. Oliveira ${ }^{b}$, J. A. Rosa ${ }^{b}$ and M. T. V. Azeredo-Oliveira ${ }^{a}$ \\ áLaboratório de Biologia Celular, Departamento de Biologia, Instituto de Biociências, Letras e Ciências Exatas - IBILCE, \\ Universidade Estadual Paulista “Júlio de Mesquita Filho" - UNESP, Rua Cristóvão Colombo, 2265, Jardim Nazareth, \\ CEP 15054-000, São José do Rio Preto, SP, Brazil

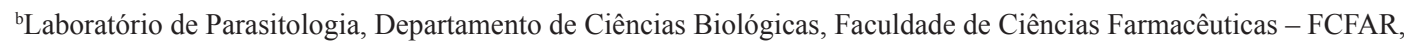 \\ Universidade Estadual Paulista “Júlio de Mesquita Filho” - UNESP, Rodovia Araraquara-Jaú, Km 1, CEP 14801-902, \\ Araraquara, SP, Brazil \\ *e-mail: e-mail: kaiochaboli@hotmail.com
}

Received: July 28, 2016 - Accepted: August 15, 2016 - Distributed: February 28, 2018

\section{Scientific Note}

Currently 153 species of Triatominae subfamily are known, divided in 18 genera and six tribes (Alevi et al., 2016; Rosa et al., 2017). The Rhodniini consisted of 23 species: three of the Psammolestes genus and 20 of the Rhodnius genus.

Cytogenetic analysis on the species of the Rhodnius genus showed chromosomal homogeneity, since all species are the same karyotype, namely, $2 \mathrm{n}=22$ (20 autosomes + XY) (Pita et al., 2013; Alevi et al., 2015a; Rosa et al., 2017) and FISH markings with the 45 S probe restricted to the sex chromosomes (Pita et al., 2013). However, chromosomal intraspecific variation have been identified in R. ecuadoriensis (Pita et al., 2013) and R. pallescens (Gomez-Palacio et al., 2008).

Rhodnius prolixus is one of the main species of prolixus complex because it has a wide geographic distribution, being found in Brazil, Bolivia, Colombia, Costa Rica, El Salvador, Ecuador, Guatemala, Guyana, French Guyana, Honduras, Mexico, Nicaragua, Panama, Suriname, Trinidad and Venezuela (Galvão et al., 2003). $R$. nasutus is a species of prolixus complex observed in different Brazilian states and Argentina (Galvão et al., 2003). This species and $R$. taquarussuensis are the only species of prolixus complex which presents dispersed heterochromatin in the nucleus and autosomes (Pérez et al., 1992; Rosa et al., 2017).

Thus, this study aimed to analyze whether different populations of $R$. prolixus from Venezuela, Costa Rica and Colombia, and $R$. nasutus from Brazil and Argentina, present chromosomal intraspecific variation.

Five adult males of the $R$. prolixus of Venezuela, Colombia and Costa Rica and R. nasutus of Brazil and Argentina were analyzed the cytogenetically. The insects were provided by FCFAR/UNESP, Campus Araraquara, São Paulo, Brazil and FIOCRUZ, Rio de Janeiro, Brazil. The testicles were removed, the slides containing the seminiferous tubules were prepared by crushing and cell stained with classical cytogenetic techniques Orcein Lacto-acetic and C- Banding and examined under a light microscopy.
Chromosomal intraspecific variation was not observed for the specimens of $R$. prolixus and $R$. nasutus from different countries, because all specimens showed the same karyotype, the same morphological characteristics for the autosomes and sex chromosomes and the same pattern of constitutive heterochromatin (Table 1).

Absence of chromosomal intraspecific variation was also observed for R. neglectus (Alevi et al., 2015b), Panstrongylus megistus (Alevi et al., 2015c), Triatoma brasiliensis (Panzera et al., 2000) and T. pseudomaculata (Imperador et al., 2016). On the other hand, chromosomal intraspecific variation was already reported in Triatominae subamily for the following species: T. sordida (Panzera et al., 1997) T. infestans (Panzera et al., 2004), T. dimidiata (Panzera et al., 2006), P. geniculatus (Crossa et al., 2002), $R$. ecuadoriensis (Pita et al., 2013) and R. pallescens (Gomez-Palacio et al., 2008).

The chromosomal homogeneity observed between $R$. prolixus from different locations corroborates the results of Pita et al. (2013) and Monteiro et al. (2003) who described the absence of polymorphism in the position of the $45 \mathrm{~S}$ gene and low variability for $R$. prolixus, respectively. Furthermore, Alevi et al. (2015d) did not observe significant differences between the reproductive aspects of these vectors, since the analysis of cystic spermatogenesis of $R$. prolixus originating in Colombia and Costa Rica, were similar.

$R$. nasutus although it also does not show intraspecific variation, can be easily distinguished from other members of the complex by heterochromatin in chromatin and chromosomes. The wealth of heterochromatin is quite peculiar in Rhodniini tribe, which could be a source of variability between populations of different countries under different evolutionary pressures, as well as observed for $R$. pallescens (Gomez-Palacio et al., 2008).

Thus, we observed that $R$. prolixus from Venezuela, Colombia and Costa Rica and $R$. nasutus from Brazil and Argentina presents chromosomal homogeneity. Our results together with the literature data for $R$. prolixus (Monteiro et al., 2003; Pita et al., 2013) can direct the 
Table 1. Chromosomal characteristics of different populations of the $R$. prolixus and R. nasutus.

\begin{tabular}{ccccc}
\hline R. prolixus & Karyotype & $\begin{array}{c}\text { Size of Sex } \\
\text { Chromosome }\end{array}$ & $\begin{array}{c}\text { Heterocromatin in } \\
\text { Autosomes }\end{array}$ & $\begin{array}{c}\text { Heterocromatin in } \\
\text { Sex Chromosomes }\end{array}$ \\
\hline Venezuela & $2 \mathrm{n}=20 \mathrm{~A}+\mathrm{XY}$ & $\mathrm{X}>\mathrm{Y}$ & Absent & Only in the $\mathrm{Y}$ \\
Colombia & $2 \mathrm{n}=20 \mathrm{~A}+\mathrm{XY}$ & $\mathrm{X}>\mathrm{Y}$ & Absent & Only in the $\mathrm{Y}$ \\
Costa Rica & $2 \mathrm{n}=20 \mathrm{~A}+\mathrm{XY}$ & $\mathrm{X}>\mathrm{Y}$ & Absent & Only in the $\mathrm{Y}$ \\
\hline R. nasutus & & & & \\
\hline Brazil & $2 \mathrm{n}=20 \mathrm{~A}+\mathrm{XY}$ & $\mathrm{X}>\mathrm{Y}$ & Present & Only in the $\mathrm{Y}$ \\
Argentina & $2 \mathrm{n}=20 \mathrm{~A}+\mathrm{XY}$ & $\mathrm{X}>\mathrm{Y}$ & Present & Only in the $\mathrm{Y}$ \\
\hline
\end{tabular}

development of specific control mechanisms by the low genetic and chromosomal variation presented in this vector.

\section{Acknowledgements}

The study was supported by Fundação de Amparo à Pesquisa do Estado de São Paulo (process number 2013/19764-0 and 2015/11372-1) and Conselho Nacional de Desenvolvimento Científico e Tecnológico (CNPq, Brazil).

\section{References}

ALEVI, K.C.C., MOREIRA, F.F.F., JURBERG, J. and AZEREDOOLIVEIRA, M.T.V., 2016. Description of diploid chromosome set of Triatoma pintodiasi (Hemiptera, Triatominae). Genetics and Molecular Research, vol. 15, no. 2, pp. 1-10.

ALEVI, K.C.C., RAVAZI, A., MENDONÇA, V.J., ROSA, J.A. and AZEREDO-OLIVEIRA, M.T.V., 2015a. Karyotype of Rhodnius montenegrensis (Hemiptera, Triatominae). Genetics and Molecular Research, vol. 14, no. 1, pp. 222-226. PMid:25729953. http:// dx.doi.org/10.4238/2015.January.16.5.

ALEVI, K.C.C., RODAS, L.A.C., TARTAROTTI, E., AZEREDOOLIVEIRA, M.T.V. and GUIRADO, M.M., 2015b. Entoepidemiology of Chagas disease in the Western region of the State of São Paulo from 2004 to 2008, and cytogenetic analysis in Rhodnius neglectus (Hemiptera, Triatominae). Genetics and Molecular Research, vol. 14, no. 2, pp. 577-5784. PMid:26125776. http:// dx.doi.org/10.4238/2015.May.29.9.

ALEVI, K.C.C., NUNES, G.M., ROSA, J.A. and AZEREDOOLIVEIRA, M.T.V., 2015c. Homogeneidade cromossômica em diferentes populações de Panstrongylus megistus do Brasil. Revista de Ciências Farmacêuticas Básica e Aplicada, vol. 36, pp. 307-310.

ALEVI, K.C.C., CASTRO, N.F.C., ROSA, J.A. and AZEREDOOLIVEIRA, M.T.V., 2015d. Cystic spermatogenesis in three species of the prolixus complex (Hemiptera: Triatominae). The Italian Journal of Zoology, vol. 82, pp. 172-178.

CROSSA, R.P., HERNÁNDEZ, M., CARACCIO, M.N., ROSE, V., VALENTE, S.A.S., VALENTE, V.C., MEJÍA, J.M., ÂNGULO, V.M., RAMÍREZ, C.M.S., ROLDÁN, J., VARGAS, F., WOLFF, M. and PANZERA, F., 2002. Chromosomal evolution trends of the genus Panstrongylus (Hemiptera, Reduviidae), vectors of Chagas disease. Infection, Genetics and Evolution, vol. 2, no. 1, pp. 47-56. PMid:12798000. http://dx.doi.org/10.1016/S15671348(02)00063-1

GALVÃO, C., CARCAVALLO, R., ROCHA, D.S. and JURBERG, J., 2003. A checklist of the current valid species of the subfamily Triatominae Jeannel, 1919 (Hemiptera, Reduviidae) and their geographical distribution, with nomenclatural and taxonomic notes. Zootaxa, vol. 202, no. 1, pp. 1-36. http://dx.doi.org/10.11646/ zootaxa.202.1.1.

GÓMEZ-PALACIO, A., JARAMILLO-OCAMPO, N., TRIANACHÁVEZ, O., SALDAÑA, A., CALZADA, J., PÉREZ, R. and PANZERA, F., 2008. Chromosome variability in the Chagas disease vector Rhodnius pallescens (Hemiptera, Reduviidae, Rhodniini). Memorias do Instituto Oswaldo Cruz, vol. 103, no. 2, pp. 160-164. PMid:18425268. http://dx.doi.org/10.1590/ S0074-02762008000200006.

IMPERADOR, C.H.L., ALEVI, K.C.C., OLIVEIRA, J., ROSA, J.A. and AZEREDO-OLIVEIRA, M.T.V., 2016. Cytogenetic analysis in Triatoma pseudomaculata Corrêa and Espínola, 1964 from different Brazilian States (Hemiptera, Triatominae). Genetics and Molecular Research, 15, no. 1, pp. 1-6.

MONTEIRO, F.A., BARRETT, T.V., FITZPATRICK, S., CORDON-ROSALES, C., FELICIANGELI, D. and BEARD, C.B., 2003. Molecular phylogeography of the Amazonian Chagas disease vectors Rhodnius prolixus and R. robustus. Molecular Ecology, vol. 12, no. 4, pp. 997-1006. PMid:12753218. http:// dx.doi.org/10.1046/j.1365-294X.2003.01802.x.

PANZERA, F., DUJARDIN, J.P., NICOLINI, P., CARACCIO, M.N., ROSE, V., TELLEZ, T., BERMÚDEZ, H., BARGUES, M.D., MAS-COMA, S., O'CONNOR, J.H. and PEREZ, R., 2004. Genomic changes of Chagas disease vector, South America. Emerging Infectious Diseases, vol. 10, no. 3, pp. 438-446. PMid:15109410. http://dx.doi.org/10.3201/eid1003.020812.

PANZERA, F., FERRANDIS, I., RAMSEY, J., ORDÒÑEZ, R., SALAZAR-SCHETTINO, P.M., CABRERA, M., MONROY, M.C., BARGUES, M.D., MAS-COMA, S., O'CONNOR, E., ÂNGULO, V.M., JARAMILLO, N., CORDON-ROSALES, C., GÓMEZ, D. and PEREZ, R., 2006. Chromosomal variation and genome size support existence of cryptic species of Triatoma dimidiata with different epidemiological importance as Chagas disease vectors. Tropical Medicine \& International Health, vol. 11, no. 7, pp. 1092-1103. PMid:16827710. http://dx.doi. org/10.1111/j.1365-3156.2006.01656.x.

PANZERA, F., HORNOS, S., PEREIRA, J., CESTAU, R., CANALE, D., DIOTAIUTI, L., DUJARDIN, J.P. and PEREZ, R., 1997. Genetic variability and geographic differentiation among three species of triatomine bugs (Hemiptera-Reduviidae). The American Journal of Tropical Medicine and Hygiene, vol. 57, no. 6, pp. 732-739. PMid:9430537.

PANZERA, F., PÉREZ, R., NICOLINI, P., HORNOS, P., COSTA, J., BORGES, E., DIOTAIUTI, L. and SCHOFIELD, C.J., 2000. Chromosome homogeneity in populations of Triatoma brasiliensis Neiva 1911 (Hemiptera-Reduviidae-Triatominae). Cadernos de Saude Publica, vol. 16, suppl. 2, pp. 83-88. PMid:11119323. http:// dx.doi.org/10.1590/S0102-311X2000000800009. 
PÉREZ, R., PANZERA, Y., SCAFIEZZO, S., MAZZELLA, M.C., PANZERA, F., DUJARDIN, J.P. and SCVORTZOFF, E., 1992. Cytogenetics as a tool for triatomine species distinction (Hemiptera-Reduviidae). Memórias do Instituto Oswaldo Cruz, vol. 87 , no. 3 , pp. 353-361.

PITA, S., PANZERA, F., FERRANDIS, I., GALVÃO, C., GÓMEZ-PALACIO, A. and PANZERA, Y., 2013. Chromosomal divergence and evolutionary inferences in Rhodniini based on the chromosomal location of ribosomal genes. Memorias do Instituto Oswaldo Cruz, vol. 108, no. 3, pp. 376-382. PMid:23778665. http://dx.doi.org/10.1590/S0074-02762013000300017.

ROSA, J.A., JUSTINO, H.H.G., NASCIMENTO, J.D., MENDONÇA, V.J., ROCHA, C.S., CARVALHO, D.B., FALCONE, R., AZEREDOOLIVEIRA, M.T.V., ALEVI, K.C.C. and OLIVEIRA, J., 2017. A new species of Rhodnius from Brazil (Hemiptera, Reduviidae, Triatominae). ZooKeys, In press. 